\title{
Effect of Some Growth Regulators' Foliar Application on Cotton Fiber Growth and Development (Elongation \& Maturation) in Two Egyptian Cotton Varieties
}

\author{
Sief, M.G. (1) Hanan, M. Arafa (D)Shimaa A. Shahat* (D)
}

\author{
Address: \\ Cotton Research Institute, Agricultural Research Center, Giza- Egypt \\ *Corresponding author: Shimaa A. Shahat, shimaaabdrabou1981@yahoo.com \\ Received:30-08-2021; Accepted:26-10-2021;Published:20-11-2021
}

doi, 10.21608/ejar.2021.92963.1141

\section{ABSTRACT}

Two field experiments were conducted at Sakha Agricultural Research Station, ARC, Kafr El-Sheikh, Egypt, in the 2017 and 2018 seasons to study the effect of growth regulators (PGRs) foliar application on cotton fiber growth and development (elongation and maturation), using Giza 93 (ELS) and Giza 94 (LS) Egyptian cotton varieties. Treatments of PGRs were made using tap water to final concentrations of 50, 100, and $150 \mathrm{ppm}$ of Indol Butyric Acid (IBA) and Mepiquat Chloride (MC), while Gibberellic Acid (GA3) concentrations were 100, 200, and 300 ppm. These treatments were performed at the beginning of flowering ( 60 days after planting). The experimental design was a split plot design in three replicates. The obtained results indicated that PGRs treatments showed significant effects on fiber growth in length, elongation rate, and secondary wall thickening along boll ages. In both seasons, 100 ppm GA3 treatment followed by 100 ppm IBA showed the highest increase in fiber elongation, elongation rate, and increased halo length in the two varieties. While MC (pix) treatment showed insignificant increases and decreases in fiber length and halo length of the two varieties. MC and IBA treatments surpassed GA3 treatments in increasing the secondary wall thickening, especially at $50 \mathrm{ppm}$ of MC. GA3 and IBA treatments exerted an overlap between elongation and cellulose deposition phases. The growing season significantly affected the degree of thickening significantly, whereas its effect on fiber elongation and its rate was of low magnitude. Season and PGR treatments had no effect on fibre perimeter.

Keywords: Cotton, quality, Fiber development, growth regulators, foliar application

\section{INTRODUCTION}

Cotton fibre is a single cell that is initiated from the outermost cell layer of the cotton ovule and undergoes five overlapping developmental stages, including differentiation, elongation, transition, secondary cell wall thickening, and maturity, and then is converted to valuable lint (Lee et al., 2007; Qin and Zhu, 2011). Cotton seed development has been divided into four distinct phases using a polynomial model: (i) cell division, (ii) cell elongation, (iii) dry matter accumulation, and (iv) maturation (Rabadia et al., 1999). These stages are influenced by environmental, genetic, physiological, and biochemical factors (Clement, 2010). During elongation, the fibre consists only of the thin primary wall and a waxy cuticle. Primary elongation begins immediately after anthesis, reaching its maximum rate around 10 days post anthesis (dpa) and can continue up to $45 \mathrm{dpa}$ in long staple cotton or cease at around $25 \mathrm{dpa}$ in shorter staples (Naithani et al., 1982; John and Keller, 1996; Smart et al., 1998). Shi and others (2006) said that the most active elongation period is from 5 to 10 days post anthesis. Secondary cell wall synthesis begins slightly before the cessation of fiber elongation ( 16 to $18 \mathrm{dpa}$ ) and continues for several weeks until maturation completes in 45 to 50 dpa and resulting a mature cotton fiber (John and Keller, 1996; Goynes et al., 1996).

Exogenous applications of some synthetic plant growth regulators (PGRs) compounds have been widely used in cotton production in an attempt to adjust plant growth and to improve lint yield and fiber quality. Since varied environments and crop production practices can have negative effects on the synthesis of some plant hormones, however external application of PGRs can have such similar functions and effects as some phytohormones, thereby allow physiological processes to continue at their normal pace. These effects may be manipulated by either (1) altering the plant hormone level, or (2) changing the capacity of the plant to respond to its natural hormones (Oosterhuis and Robertson, 2000). Therefore, it is relevant to study the effect of some plant growth regulators on the growth and development of cotton fibers. Since cotton, producers and researchers have found that chemical PGRs that promote, inhibit, or otherwise modify plant physiological or morphological processes have the ability to influence different stages of cotton fiber development and improve productivity (Aleman et al., 2008; Singh et al., 2009; Xiao et al., 2010).

Auxins and Gibberellins are a class of important promoters plant hormones involved in many physiological and developmental processes at low concentrations, whereas at higher concentrations it inhibits enlargement or is even toxic to cell (Olszewski et al., 2002; Jost et al., 2006). GA3 and auxin act synergistically or additively in stimulating cell elongation by loosening the cell wall either directly by altering wall pH or indirectly by turning on enzymes as well (Ross et al., 2003). 
Elongation is the result of turgor pressure-driven cell expansion causing the wall to stretch (Hake et al., 1991; Gould and Seagull, 2002). Previous studies of (Kosmidou-Dimitropoulou and Board, 1986; Gialvalis and Seagull, 2001) cleared that post-anthesis exogenous treatment with gibberellic acid produced the largest increase in fiber initiation, whereas auxins showed a week effect, they might be not essential for fiber initiation.

Using cotton fiber as a model system in plant in vitro, the exogenous application of GA3 remarkably improved the fiber length of the short and middle staple cultivars as compared with the long staple one (Gokani and Thaker, 2001 and 2002). Short staple cultivars are deficient in their capacity to synthesize the sufficient amount of promontory PGRs (Gokani and Thaker, 2002b; Bhatt, 2007).

There are two different viewpoints about the effect of plant growth regulators on cellulose synthesis and secondary wall thickening. Kosmidou-Dimitropoulou and Board (1986) considered that auxin is necessary for secondary wall thickening. (Salisbury and Ross, 1992) reported that auxins stimulate cell elongation and cause wall loosening, a term describing the more rapidly extensible or plastic nature of walls from cells treated with auxins. The hypothesis proposes that auxins cause receptor cells in stem sections to secrete $\mathrm{H}^{+}$into their surrounding primary walls. These $\mathrm{H}^{+}$ions result in a lowering of the $\mathrm{pH}$ so that wall loosening and fast growth occur. The low $\mathrm{pH}$ presumably allows certain cell wall- degrading enzymes that are inactive at a higher $\mathrm{pH}$ to function. These cell wall-degrading enzymes purportedly break bonds in wall polysaccharides, allowing the walls to stretch more easily, moreover (Marre, 1977; Guilfoyle, 1986; Key, 1989) found that at the cellular level, auxin effects include increases in the nucleotides DNA and RNA, and subsequent involvement in protein and enzyme synthesis; increases in proton exchange, membrane charge, and potassium uptake and rapid changes in gene activity. Olszewski et al. (2002) found that GA might enhance carbon compounds transformation to cellulose and secondary cell wall synthesis via up-regulating sucrose synthase expression in cotton fibers. Higher GA levels in transgenic cotton fibers significantly increased cell wall thickness and cellulose contents of mature fibers, in addition; exogenous application of gibberellic acid induces significant increases in fiber length during secondary wall synthesis (Seagull et al.,2000). On the other hand, GA3 and auxin had no effect on cellulose synthesis, furthermore (Francey et al., 1989; Jaquet et al., 1982; Pillonel and Meier, 1985), Singh et al. (2009) reported that auxins are responsible for cell elongation and required for primary elongation and timing of secondary wall synthesis in cotton fiber development. The use of a synthetic auxin delayed the onset of high-rate cellulose synthesis by at least 6 days in ovule culture was investigated (Xiao et al., 2010). Seagull et al. (2000) stated that cotton fibers appear to be an exception, with cell elongation continuing during secondary wall synthesis, with external application by gibberellic acid, and indole-3-acetic acid. However, a growth retardant such as mepiquat chloride (pix) by the nature of its effect on plant growth, may often elicit growth features such as earlier maturity of the developing boll and a yield enhancement (Zhao and Oosterhuis, 2000). In general, mepiquat chloride causes a significantly earlier maturity about $50 \%$ of the time (Oosterhuis et al., 1991), in addition reduces or inhibits enzymes acting in the production of gibberellic acid concentrations in plants and consequently, inhibits growth and cell elongation (Halmann, 1990; Rademacher, 2000; Stewart et al., 2001).

Therefore, the main objective of this research work is to study the effects of growth regulators (exogenous hormones) foliar application on cotton fiber growth and development, i.e. the rate of fiber elongation, the increase in fiber length along the different boll ages, fiber secondary wall thickening, and the impact of these treatments on fiber perimeter (fineness), using two Egyptian cotton varieties having different staple lengths.

\section{MATERIAL AND METHODS}

Two field experiments were carried out in the 2017 and 2018 seasons at Sakha Agricultural Research Station, Kafr El-Sheikh, Egypt, in dependence on the Agricultural Research Center, Giza, Egypt. Using two Egyptian cotton cultivars, Giza 93 (ELS) and Giza 94 (LS) (Gossypium barbadense L.), The planting date was April 30 in both seasons. The preceding winter crop was Egyptian clover. Cotton planting was done by the local method of digging 5 to 7 seeds in each hill by hand with a $25 \mathrm{~cm}$ distance between hills. Thinning was conducted after 35 days of sowing to better maintain two plants per hill. Three plant growth regulators (PGRs) were used as foliar spray applications in different concentrations: (a) Auxins; Indole Butyric Acid (IBA) (1H-Indole-3-butanoic acid); (b) Mepiquat Chloride (Pix)-MC-1,I-dimethylpiperidinium chloride) to induce cell division, using tap water to a final various concentrations of 50, 100, and $150 \mathrm{ppm}$ ); and (c) Gibberellic Acid (GA3) to induce cell elongation. GA3 concentrations were 100,200 , and $300 \mathrm{ppm}$. The control treatment was sprayed with tap water. All the PGR treatments were applied at the beginning of flowering, 60 days after planting. The experimental design was a split-plot design with three replicates. The three plant growth regulators (PGRs) were randomly assigned to main plots and their concentrations were assigned to sub-plots. The sub-plot area was $14.4 \mathrm{~m} 2$ and contained six ridges of $4.0 \mathrm{~m}$ long and $70 \mathrm{~cm}$ apart (56000 cotton plants/feddan). Cotton experts. The cultural practices, including irrigation, application of fertilisers and insecticides, etc., were conducted as recommended by Cotton. 
Table 1. Temperature degrees during cotton growing season in 2017 and 2018 seasons.

\begin{tabular}{|c|c|c|c|c|c|c|c|}
\hline \multirow{3}{*}{ Month } & \multirow{3}{*}{ Period } & \multicolumn{3}{|c|}{ Temperature $\left({ }^{\circ} \mathrm{C}\right)$} & \multicolumn{3}{|c|}{2018 season } \\
\hline & & \multicolumn{3}{|c|}{2017 season } & \multicolumn{3}{|c|}{2018 season } \\
\hline & & Max. & Min. & Mean & Max. & Min. & Mean \\
\hline \multirow[t]{3}{*}{ May } & $1-10$ & 30.69 & 19.55 & 25.12 & 29.71 & 19.55 & 24.63 \\
\hline & $11-20$ & 30.29 & 26.30 & 28.30 & 29.69 & 26.30 & 28.00 \\
\hline & $21-30$ & 30.90 & 25.95 & 28.43 & 30.90 & 24.22 & 27.56 \\
\hline Average & & 30.63 & 23.93 & 27.28 & 30.10 & 23.36 & 26.73 \\
\hline \multirow[t]{3}{*}{ June } & $1-10$ & 32.43 & 27.75 & 30.09 & 32.50 & 24.68 & 28.59 \\
\hline & $11-20$ & 30.66 & 27.81 & 29.24 & 32.69 & 25.63 & 29.16 \\
\hline & $21-30$ & 34.00 & 28.88 & 31.44 & 32.51 & 25.40 & 28.96 \\
\hline Average & & 32.36 & 28.15 & 30.25 & 32.57 & 25.24 & 28.90 \\
\hline \multirow[t]{3}{*}{ July } & $1-10$ & 34.73 & 29.42 & 32.08 & 33.95 & 25.69 & 29.82 \\
\hline & $11-20$ & 34.46 & 29.14 & 31.80 & 34.18 & 25.09 & 29.64 \\
\hline & $21-30$ & 33.49 & 28.48 & 30.99 & 34.50 & 25.31 & 29.91 \\
\hline Average & & 34.23 & 29.01 & 31.62 & 34.21 & 25.36 & 29.79 \\
\hline \multirow[t]{3}{*}{ August } & $1-10$ & 34.22 & 28.79 & 31.51 & 34.31 & 25.52 & 29.92 \\
\hline & $11-20$ & 33.88 & 29.22 & 31.55 & 33.90 & 25.23 & 29.57 \\
\hline & $21-30$ & 33.52 & 27.40 & 30.46 & 33.47 & 27.40 & 30.44 \\
\hline Average & & 33.87 & 28.47 & 31.17 & 33.89 & 26.05 & 29.97 \\
\hline \multirow[t]{3}{*}{ September } & $1-10$ & 33.13 & 25.85 & 29.49 & 34.28 & 24.23 & 29.26 \\
\hline & $11-20$ & 33.64 & 26.02 & 29.83 & 32.62 & 24.02 & 28.32 \\
\hline & $21-30$ & 30.18 & 25.83 & 28.01 & 32.64 & 24.41 & 28.53 \\
\hline Average & & 32.32 & 25.90 & 29.11 & 33.18 & 24.22 & 28.70 \\
\hline
\end{tabular}

During flowering, some flowers from different plants were labelled on the day of anthesis to enable the collection of bolls of a known age. Bolls of 7 ages were used in this study: 5, 10, 15, 20, 30, 40, and 45-48 days from flowering. The selected bolls of each age were taken from the plant and transported directly to the Lab of Fiber Structural Properties, Cotton Fiber Res. Department, Cotton Res. Institute to measure fibre perimeter (3.14 x diameter) and follow up the development of fibre elongation and cellulose deposition (maturity) under different ages. To follow up fibre elongation and its rate, three different bolls from different plants were taken and opened, then placed in boiling water (with a few drops of $0.1 \mathrm{~N} \mathrm{HCl}$ ) to allow seeds to separate from each other. Ten fibres were taken from each side of the clazal part of the seed and measured their length using a special scale. The obtained length data was averaged to represent the fibre length of each boll age. Cellulose deposition was expressed as a degree of thickening and was calculated according to the formula of Lord (1981).

$$
\text { Degree of thickening }=\frac{\text { Area of cellulose }}{\text { (Circular cross section area) }} \times 100
$$

Fiber Swollen perimeter, area of the circular cross section and area of cellulose was calculated from green boll data of fiber diameter and lumen diameter. Halo length was measured from the seed cotton of each treatment using a special scale. The obtained data were subjected to Analysis of variance and LSD 5\% test was employed to compare the different means of each studied character. The analysis of variance and LSD were carried out according to (Snedecor and Cochoran, 1986). It is worthy to report that applying Parttelet test to the obtained results and found not significant indicating the homogeneity of the obtained data; therefore, the data of each character was subjected to combine analysis of variance. Data of each variety was analyzed separately.

\section{RESULTS}

Aiming to study the effects of growth regulators' foliar application on cotton fibre growth and development (elongation, cellulose deposition, and perimeter), it was necessary to follow up on fibre elongation and cellulose deposition and perimeter of the different boll ages from ( 5 days) boll age to the boll final age just before boll opening (45-48 days).

\section{Effect of the growth regulators foliar application on cotton fiber length and fiber elongation rate:}

The results in Table (2) and Figure (1) indicated that foliar application of the growth regulator treatments and their concentrations significantly increased fibre length along the different boll ages, fibre elongation rate, and halo length in the two cotton varieties in both seasons compared to the control. However, Pix treatments showed insignificant increases and decreases in fibre length of the different boll ages and halo length in both varieties in most cases. The combined analysis of fibre elongation data of G.93 and G.94 revealed that the GA3 growth regulator showed the highest increase in fibre length of the different boll ages and accelerated fibre elongation more than the other two growth regulators, while IBA ranked second. MC (pix) did not show any significant increase and/or decrease in these studied traits. 
Table 2. The effects of the growth regulators and their concentrations on fibre length and elongation and its rate of G.93 and G.94 varieties in the 2017 and 2018 seasons.

\begin{tabular}{|c|c|c|c|c|c|c|c|c|c|c|c|c|c|c|c|c|c|c|}
\hline \multirow{4}{*}{ 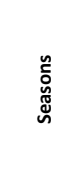 } & \multirow[b]{4}{*}{\begin{tabular}{l} 
:̊ \\
\hdashline
\end{tabular}} & \multirow{4}{*}{$\begin{array}{l}\text { Concent - } \\
\text { Rations } \\
\text { (C) }\end{array}$} & \multicolumn{16}{|c|}{ Fiber length and elongation rate $(\mathrm{mm})$} \\
\hline & & & \multicolumn{8}{|c|}{ G.93 } & \multirow{2}{*}{\multicolumn{8}{|c|}{ G.94 }} \\
\hline & & & & & & & & & & Boll age & & & & & & & & \\
\hline & & & $\begin{array}{c}5 \\
\text { days }\end{array}$ & $\begin{array}{l}10 \\
\text { day }\end{array}$ & $\begin{array}{c}15 \\
\text { day }\end{array}$ & $\begin{array}{c}20 \\
\text { day }\end{array}$ & $\begin{array}{c}30 \\
\text { day }\end{array}$ & $\begin{array}{l}40 \\
\text { day }\end{array}$ & $\begin{array}{l}\begin{array}{c}45-48 \\
\text { days }\end{array} \\
\end{array}$ & 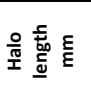 & 5 days & $\begin{array}{l}10 \\
\text { day }\end{array}$ & $\begin{array}{c}15 \\
\text { day }\end{array}$ & $\begin{array}{c}20 \\
\text { day }\end{array}$ & $\begin{array}{c}30 \\
\text { day }\end{array}$ & $\begin{array}{l}40 \\
\text { day }\end{array}$ & $\begin{array}{l}45-48 \\
\text { day }\end{array}$ & 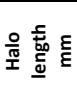 \\
\hline \multirow{14}{*}{ సิ } & & Control & 8.2 & 22.3 & 28.2 & 34.5 & 36.5 & 36.9 & 37.0 & 36.8 & 6.9 & 17.8 & 22.7 & 30.2 & 33.3 & 34.3 & 34.4 & 34.3 \\
\hline & \multirow{4}{*}{ 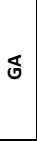 } & $100 \mathrm{ppm}$ & 14.8 & 28.2 & 31.6 & 38.3 & 39.0 & 39.1 & 39.3 & 38.7 & 9.0 & 22.2 & 27.9 & 33.6 & 35.1 & 35.7 & 35.7 & 35.3 \\
\hline & & 200 ppm & 14.1 & 27.0 & 30.6 & 37.5 & 39.0 & 38.4 & 38.6 & 37.6 & 8.3 & 22.0 & 27.2 & 32.6 & 35.1 & 34.9 & 35.2 & 34.8 \\
\hline & & 300 ppm & 13.9 & 26.5 & 30.1 & 36.8 & 39.0 & 37.4 & 37.4 & 37.0 & 7.6 & 20.2 & 26.0 & 32.0 & 34.7 & 34.5 & 34.7 & 34.3 \\
\hline & & Mean & 14.3 & 27.2 & 30.8 & 37.5 & 39.0 & 38.2 & 38.5 & 37.8 & 8.3 & 21.5 & 27.0 & 32.7 & 35.0 & 35.1 & 35.1 & 34.8 \\
\hline & \multirow{4}{*}{ 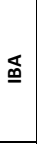 } & $50 \mathrm{ppm}$ & 12.0 & 26.0 & 30.1 & 34.3 & 35.3 & 36.8 & 36.8 & 36.7 & 8.0 & 19.8 & 24.3 & 31.7 & 34.5 & 34.4 & 34.6 & 34.7 \\
\hline & & 100 ppm & 13.3 & 27.4 & 30.4 & 36.7 & 37.2 & 37.5 & 37.5 & 37.3 & 8.0 & 21.8 & 25.0 & 32.2 & 34.8 & 35.0 & 34.9 & 34.5 \\
\hline & & $150 \mathrm{ppm}$ & 12.6 & 26.2 & 29.7 & 35.0 & 36.5 & 37.0 & 37.8 & 36.4 & 8.0 & 20.1 & 23.8 & 31.8 & 34.4 & 34.9 & 34.8 & 34.6 \\
\hline & & Mean & 12.6 & 26.5 & 30.1 & 35.7 & 36.8 & 37.2 & 37.2 & 36.9 & 8.0 & 20.4 & 24.7 & 31.9 & 34.6 & 34.8 & 34.8 & 34.6 \\
\hline & \multirow{5}{*}{$\underline{\Sigma}$} & $50 \mathrm{ppm}$ & 8.11 & 22.3 & 28.2 & 34.7 & 36.6 & 36.9 & 36.8 & 36.0 & 6.8 & 17.3 & 22.8 & 30.0 & 33.0 & 34.0 & 34.2 & 34.2 \\
\hline & & 100 ppm & 8.0 & 22.5 & 28.4 & 34.5 & 36.5 & 36.7 & 36.8 & 36.7 & 6.7 & 17.9 & 22.6 & 30.1 & 33.5 & 34.1 & 34.3 & 34.1 \\
\hline & & 150 ppm & 8.2 & 22.3 & 28.1 & 34.9 & 36.8 & 36.9 & 37.0 & 36.7 & 6.8 & 17.7 & 22.6 & 30.0 & 33.2 & 34.0 & 34.3 & 34.1 \\
\hline & & Mean & 8.1 & 22.2 & 28.2 & 34.7 & 36.6 & 36.8 & 37.0 & 36.7 & 6.7 & 7.7 & 22.7 & 30.0 & 33.3 & 34.0 & 34.2 & 34.1 \\
\hline & & Mean & 11.7 & 24.5 & 29.3 & 35.5 & 37.2 & 37.2 & 37.4 & 37.1 & 7.7 & 19.5 & 24.6 & 31.2 & 34.6 & 34.6 & 34.6 & 34.4 \\
\hline \multirow{14}{*}{$\stackrel{\infty}{\stackrel{\sim}{\sim}}$} & & Control & 8.0 & 21.9 & 28.4 & 33.5 & 36.7 & 36.7 & 36.6 & 36.5 & 6.5 & 17.6 & 22.5 & 29.9 & 33.1 & 34.0 & 34.2 & 34.0 \\
\hline & \multirow{4}{*}{ 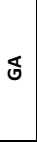 } & 100 ppm & 14.6 & 28.7 & 31.9 & 38.0 & 38.6 & 39.1 & 39.1 & 38.9 & 8.8 & 22.1 & 27.8 & 33.5 & 35.0 & 35.5 & 35.5 & 35.0 \\
\hline & & 200 ppm & 14.0 & 27.2 & 30.4 & 37.3 & 39.0 & 38.6 & 38.4 & 37.4 & 8.0 & 21.0 & 27.0 & 32.3 & 35.1 & 34.8 & 35.1 & 34.4 \\
\hline & & 300 ppm & 13.7 & 26.1 & 29.1 & 37.0 & 37.8 & 37.5 & 37.4 & 37.0 & 7.8 & 20.0 & 26.0 & 32.2 & 34.5 & 34.5 & 34.4 & 34.3 \\
\hline & & Mean & 14.0 & 27.1 & 30.6 & 37.4 & 38.5 & 38.4 & 38.3 & 37.8 & 8.2 & 21.0 & 27.0 & 32.6 & 34.9 & 34.9 & 35.0 & 34.6 \\
\hline & \multirow{4}{*}{ 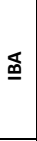 } & $50 \mathrm{ppm}$ & 11.8 & 25.6 & 30.0 & 34.4 & 35.0 & 36.5 & 36.7 & 36.9 & 8.1 & 19.4 & 24.1 & 31.5 & 34.2 & 34.4 & 34.8 & 34.4 \\
\hline & & 100 ppm & 13.1 & 27.1 & 30.0 & 36.5 & 37.2 & 37.4 & 36.9 & 37.0 & 8.0 & 20.8 & 26.3 & 32.5 & 34.8 & 34.8 & 34.8 & 34.4 \\
\hline & & $150 \mathrm{ppm}$ & 12.4 & 25.9 & 30.0 & 35.3 & 36.3 & 36.8 & 37.0 & 36.7 & 8.0 & 20.5 & 23.8 & 31.4 & 34.6 & 34.5 & 34.8 & 34.4 \\
\hline & & Mean & 12.5 & 26.2 & 30.0 & 35.4 & 36.5 & 36.9 & 36.9 & 36.7 & 8.0 & 20.2 & 24.7 & 31.8 & 34.5 & 34.6 & 34.8 & 34.4 \\
\hline & \multirow{5}{*}{$\stackrel{U}{\Sigma}$} & $50 \mathrm{ppm}$ & 8.3 & 22.1 & 28.0 & 34.5 & 36.8 & 36.9 & 37.0 & 36.8 & 6.5 & 17.6 & 22.7 & 30.3 & 33.2 & 34.0 & 34.0 & 34.0 \\
\hline & & $100 \mathrm{ppm}$ & 8.0 & 22.2 & 28.2 & 34.5 & 36.7 & 36.9 & 36.8 & 36.4 & 6.6 & 17.7 & 22.7 & 30.1 & 33.2 & 34.2 & 34.0 & 33.8 \\
\hline & & 150 ppm & 8.1 & 22.1 & 28.3 & 34.7 & 36.6 & 36.7 & 37.0 & 37.6 & 6.8 & 17.7 & 22.7 & 30.0 & 33.2 & 34.0 & 34.3 & 33.2 \\
\hline & & Mean & 8.2 & 22.1 & 28.2 & 34.6 & 36.7 & 36.8 & 37.0 & 36.7 & 6.7 & 17.7 & 22.7 & 30.1 & 33.2 & 34.1 & 34.1 & 34.0 \\
\hline & & & 11.6 & 24.3 & 29.3 & 34.7 & 37.2 & 37.1 & 37.2 & 36.9 & 7.4 & 19.1 & 22.9 & 31.1 & 33.9 & 34.4 & 34.5 & 34.2 \\
\hline \multirow{14}{*}{ 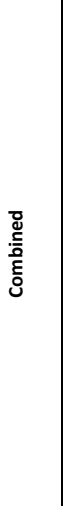 } & & Control & 8.1 & 22.1 & 28.3 & 34.5 & 36.6 & 36.8 & 36.8 & 36.6 & 7.7 & 17.7 & 22.6 & 30.0 & 33.2 & 34.2 & 34.3 & 34.1 \\
\hline & \multirow{4}{*}{ త } & 100 ppm & 14.7 & 28.1 & 31.7 & 38.2 & 38.9 & 39.1 & 39.3 & 38.8 & 8.9 & 22.2 & 27.8 & 33.5 & 35.0 & 35.5 & 35.6 & 35.2 \\
\hline & & 200 ppm & 14.0 & 27.1 & 30.5 & 37.4 & 39.0 & 38.5 & 38.5 & 37.5 & 8.1 & 21.5 & 27.1 & 32.4 & 35.1 & 34.8 & 35.0 & 34.6 \\
\hline & & 300 ppm & 13.8 & 26.3 & 29.9 & 36.9 & 38.9 & 37.3 & 37.4 & 37.0 & 7.0 & 20.2 & 26.0 & 32.1 & 34.7 & 34.5 & 34.6 & 34.3 \\
\hline & & Mean & 14.2 & 27.2 & 30.7 & 37.5 & 38.9 & 38.3 & 38.4 & 37.8 & 8.3 & 21.3 & 27.0 & 32.7 & 34.9 & 35.0 & 35.1 & 34.7 \\
\hline & \multirow{4}{*}{ 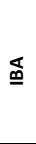 } & $50 \mathrm{ppm}$ & 11.9 & 25.2 & 30.1 & 34.4 & 36.1 & 36.7 & 36.9 & 36.9 & 8.0 & 19.6 & 24.3 & 31.6 & 34.3 & 34.4 & 34.7 & 34.5 \\
\hline & & 100 ppm & 13.2 & 27.3 & 30.2 & 36.6 & 37.2 & 37.4 & 47.5 & 37.1 & 8.0 & 21.0 & 26.2 & 32.4 & 34.8 & 34.9 & 34.8 & 34.5 \\
\hline & & 150 ppm & 13.8 & 26.3 & 29.9 & 36.9 & 38.9 & 37.3 & 37.4 & 37.0 & 7.0 & 20.2 & 26.0 & 32.1 & 34.7 & 34.5 & 34.6 & 34.3 \\
\hline & & Mean & 12.5 & 26.4 & 30.0 & 35.5 & 36.6 & 37.0 & 37.1 & 36.8 & 8.0 & 20.2 & 24.6 & 31.9 & 34.6 & 34.7 & 34.8 & 34.5 \\
\hline & & $50 \mathrm{ppm}$ & 8.22 & 22.2 & 25.1 & 34.6 & 36.7 & 36.9 & 37.0 & 36.7 & 6.6 & 17.6 & 22.3 & 30.2 & 33.1 & 34.0 & 34.2 & 34.1 \\
\hline & 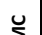 & 100 ppm & 8.0 & 22.3 & 28.3 & 34.5 & 36.6 & 36.8 & 37.0 & 36.6 & 6.7 & 17.8 & 22.7 & 30.1 & 33.3 & 34.1 & 34.2 & 34.0 \\
\hline & 2 & 150 ppm & 8.1 & 22.2 & 28.2 & 34.7 & 36.7 & 36.8 & 36.8 & 36.7 & 6.8 & 17.7 & 22.6 & 30.1 & 33.2 & 34.0 & 34.3 & 34.2 \\
\hline & & Mean & 8.1 & 22.2 & 28.2 & 34.6 & 36.7 & 36.8 & 37.0 & 36.6 & 6.7 & 17.7 & 22.7 & 31.1 & 33.2 & 34.0 & 34.2 & 34.1 \\
\hline & & G.Mean & 11.6 & 22.2 & 28.2 & 34.5 & 36.6 & 36.8 & 37.0 & 36.7 & 7.7 & 19.3 & 22.6 & 31.2 & 34.3 & 34.5 & 34.5 & 34.1 \\
\hline
\end{tabular}

*Combined LSD 5\% G.93 Combined LSD 5\% Giza 94 respectively (S): N.S N.S, (R): $0.22 \quad 0.19$, (C): 0.250 .23 , (SxR): N.S N.S, (SxC): N.S N.S, $(\mathrm{RxC}): 0.32 \quad 0.30,(\mathrm{~S} \times \mathrm{R} \times \mathrm{C}): 0.390 .53$

Foliar application treatment of $100 \mathrm{ppm}$ of GA3 surpassed all the other treatments of the growth regulators in increasing fiber length of the different boll ages and in accelerating the elongation rate of G.93 and G.94. It recorded 14.70, 28.10, $31.73,38.16,38.86,39.10,39.25$, and $38.80 \mathrm{~mm}$ for fiber length of $5,10,15,20,30,40,45-48$ days and halo length of $\mathrm{G} .93$, respectively, compared to $8.12,22.12,28.30,34.48,36.58,36.78,36.81$, and $36.61 \mathrm{~mm}$ for fiber length of the same boll ages and halo length of the control treatment. While, $100 \mathrm{ppm}$ of IBA foliar treatment exceeded the other two treatments of IBA in its effect on fiber length and elongation rate, it recorded 13.20, 27.25, 30.22, 36.58, 37.20, 37.44, 37.50 and 37.14 $\mathrm{mm}$ for fiber length of those boll ages and halo length. Giza 94 cotton variety, showed the same trend as Giza 93 regarding the effect of growth regulators on the fiber length of the different boll ages, fiber elongation rate and halo length. In G.94, $100 \mathrm{ppm}$ of GA3 recorded 8.88, 22.18, 27.82, 33.50, 35.00, 35.54, 35.60, and $35.18 \mathrm{~mm}$ for fiber length in 5, 10, 15, 20, 30, $40,45-48$ days (final boll age just before opening) and hallo length, respectively, as compared to $6.72,17.72,22.60,30.03$, $33.22,34.16,34.28$, and $34.14 \mathrm{~mm}$ for fiber length of the same boll ages and hallow length of the control treatment. Whilst, $100 \mathrm{ppm}$ of IBA foliar treatment exceeded the other two treatments of IBA in its effect on fiber length and elongation rate of Giza 94, it recorded 8.00, 21.00, 26.22, 32.44, 34.80, 34.89, 34.78, and $34.45 \mathrm{~mm}$ for fiber length of those boll ages and halo length. 
Effect of the growth regulators foliar application on cellulose deposition (fiber maturity):

The results in Table (3) and figure (2) indicated that foliar application of the growth regulators treatments promoted and increased significantly cotton fiber secondary wall cellulose deposition (fiber maturity) expressed in degree of thickening starting the $20^{\text {th }}$ day up to the $45^{\text {th }}-48^{\text {th }}$ boll age (final boll age just before opening) of the two varieties in both seasons compared to the control special1y in the young boll ages 20,25 and 30 days. However, the increase in cellulose deposition in the old boll ages 40, $45-48$ days was relatively little compared to that increase in the young boll ages. Moreover growing season exerted a significant effect on cellulose deposition (secondary wall thickening) in both of the two studied varieties. Degree of thickening of Giza 93 averaged in 2017 season 36.1, 64.4, 79.6, 84.2, 89.0 and 94.7 \%, and averaged in 2018 season; 33.1, $55.170 .3,78.386 .5$ and $91.3 \%$, in the boll ages 20, 25, 30, 40, and 45-48 days respectively, while Giza 94 averaged in 2017 season; 32.0, 75.6, 81.2, 87.5, and $92.5 \%$ and averaged in 2018 season; 30.1, 58.4, 72.8, 78.4, 84.7 and $90.2 \%$ for the same boll ages respectively. In both of the studied cotton varieties, G.93 and Giza 94, the combined analysis of the two seasons revealed that Pix and IBA growth regulator treatments showed a higher increase in cellulose deposition and its rate compared to GA3 treatments, which showed a lower increase in the degree of thickening of the secondary wall of the cotton fibres of the two varieties. Both Pix and IBA showed nearly the same mean values of degree of thickening in the two varieties along the different boll ages studied, except for the $50 \mathrm{ppm}$ treatment of Pix, which recorded higher values of this trait along the different boll ages compared to the other treatments of the three growth regulators. It was recorded in Giza 93 that 39.2, 68.1, 83.3, 86.7, 90.1, and $95.0 \%$ for the degree of thickening in 20, 25, 30, 35, 40, and 45-48 day boll ages, respectively, compared to $14.9,30.5,45.7,62.3,79.0$, and $84.8 \%$ in the control treatment, respectively. The same treatment (50 ppm treatment of Pix) was recorded in Giza 94; 36.8, 66.2, 81.2, 84.8, 86.3, and $95.4 \%$ in the aforementioned boll ages, respectively, compared to $17.0,30.3,55,4,64.2,75.0$, and $85.8 \%$ for the same boll ages in the control treatment.

Table 3. Effect of the growth regulators and its concentrations on degree of thickening (fiber maturity) and its rate of G.93 and G.94 varieties in 2017 and 2018 seasons

\begin{tabular}{|c|c|c|c|c|c|c|c|c|c|c|c|c|c|c|}
\hline \multirow{5}{*}{ Seasons } & \multirow{5}{*}{$\begin{array}{r}\text { PGR } \\
\text { (R) }\end{array}$} & \multirow[t]{5}{*}{ Cocentrations (c) } & \multicolumn{6}{|c|}{ Degree of thickening \% } & \multicolumn{6}{|c|}{ Degree of thickening \% } \\
\hline & & & \multicolumn{6}{|c|}{ G.93 } & \multicolumn{6}{|c|}{ G.94 } \\
\hline & & & \multicolumn{6}{|c|}{ Boll Ages } & \multicolumn{6}{|c|}{ Boll Ages } \\
\hline & & & 20 & 25 & 30 & 35 & 40 & $45-48$ & 20 & 25 & 30 & 35 & 40 & $45-48$ \\
\hline & & & Day & days & days & Days & Days & days & Day & Days & days & Days & days & Days \\
\hline \multirow[t]{14}{*}{2017} & & Control & 16.40 & 31.6 & 46.8 & 63.5 & 80.1 & 90.1 & 18.60 & 32.2 & 57.3 & 66.1 & 76.9 & 89.7 \\
\hline & \multirow[t]{4}{*}{ GA } & $100 \mathrm{ppm}$ & 25.62 & 47.4 & 62.6 & 73.8 & 85.1 & 91.2 & 33.71 & 62.7 & 75.7 & 81.6 & 89.5 & 93.4 \\
\hline & & $200 \mathrm{ppm}$ & 31.32 & 49.3 & 64.5 & 76.5 & 88.5 & 92.2 & 31.19 & 60.9 & 74.0 & 79.1 & 86.1 & 91.6 \\
\hline & & 300 ppm & 36.42 & 53.6 & 68.8 & 79.9 & 91.0 & 92.9 & 32.40 & 56.7 & 71.7 & 78.1 & 84.4 & 91.1 \\
\hline & & Mean & 31.43 & 50.1 & 65.3 & 76.7 & 88.2 & 92.1 & 31.10 & 60.1 & 73.8 & 79.6 & 86.7 & 92.0 \\
\hline & \multirow[t]{4}{*}{ IBA } & 50 ppm & 35.40 & 61.8 & 77.0 & 82.0 & 87.1 & 93.8 & 29.30 & 58.1 & 73.2 & 79.0 & 85.8 & 92.1 \\
\hline & & 100 ppm & 40.42 & 67.3 & 82.5 & 86.2 & 89.8 & 94.5 & 31.38 & 64.2 & 75.2 & 82.7 & 87.9 & 93.0 \\
\hline & & $150 \mathrm{ppm}$ & 38.20 & 62.9 & 78.1 & 84.0 & 89.9 & 94.3 & 30.22 & 59.1 & 74.1 & 78.7 & 84.7 & 91.9 \\
\hline & & Mean & 38.01 & 64.0 & 79.2 & 84.1 & 88.9 & 94.2 & 30.40 & 60.5 & 74.2 & 80.1 & 86.1 & 92.3 \\
\hline & \multirow[t]{5}{*}{ MC } & 50 ppm & 40.30 & 69.1 & 84.3 & 87.7 & 91.1 & 96.0 & 37.30 & 68.0 & 83.1 & 86.6 & 90.1 & 95.4 \\
\hline & & 100 ppm & 38.41 & 65.3 & 80.5 & 85.0 & 89.5 & 94.5 & 33.02 & 61.1 & 76.1 & 81.6 & 87.1 & 92.3 \\
\hline & & $150 \mathrm{ppm}$ & 35.52 & 58.8 & 74.0 & 79.8 & 86.5 & 93.6 & 28.18 & 57.9 & 72.9 & 80.5 & 88.0 & 91.3 \\
\hline & & Mean & 38.07 & 64.4 & 79.6 & 84.2 & 89.0 & 94.7 & 32.82 & 62.3 & 77.4 & 82.9 & 88.4 & 93.0 \\
\hline & & G Mean & 35.82 & 57.3 & 72.5 & 80.5 & 88.6 & 93.4 & 31.44 & 61.2 & 75.6 & 81.2 & 87.5 & 92.5 \\
\hline \multirow[t]{14}{*}{2018} & & Control & 14.60 & 29.3 & 44.5 & 61.2 & 77.8 & 88.8 & 15.42 & 28.4 & 53.5 & 62.3 & 73.1 & 85.9 \\
\hline & \multirow[t]{4}{*}{ GA } & $100 \mathrm{ppm}$ & 28.40 & 45.2 & 60.4 & 71.6 & 82.9 & 89.0 & 33.00 & 60.6 & 73.7 & 79.6 & 87.5 & 91.3 \\
\hline & & 200 ppm & 30.31 & 47.1 & 62.3 & 74.3 & 86.3 & 90.0 & 30.08 & 58.9 & 71.9 & 77.0 & 84.1 & 89.6 \\
\hline & & 300 ppm & 32.00 & 51.4 & 66.6 & 77.7 & 88.8 & 90.7 & 28.22 & 54.6 & 69.7 & 76.0 & 82.3 & 89.0 \\
\hline & & Mean & 30.34 & 47.9 & 63.1 & 74.5 & 86.0 & 89.9 & 31,43 & 58.0 & 71.7 & 77.5 & 84.6 & 90.0 \\
\hline & \multirow[t]{4}{*}{ IBA } & $50 \mathrm{ppm}$ & 34.10 & 59.6 & 74.8 & 79.9 & 84.9 & 91.6 & 24.60 & 55.9 & 71.0 & 76.8 & 83.6 & 89.9 \\
\hline & & 100 ppm & 38.40 & 65.1 & 80.3 & 84.0 & 87.6 & 92.3 & 34.12 & 62.0 & 73.0 & 80.5 & 85.7 & 90.8 \\
\hline & & $150 \mathrm{ppm}$ & 38.00 & 60.7 & 75.9 & 81.8 & 87.8 & 92.1 & 30.38 & 56.9 & 71.9 & 76.5 & 82.5 & 89.7 \\
\hline & & Mean & 36.84 & 61.8 & 77.0 & 81.9 & 86.8 & 92.0 & 29.70 & 58.3 & 72.0 & 77.9 & 83.9 & 90.1 \\
\hline & \multirow[t]{5}{*}{ MC } & $50 \mathrm{ppm}$ & 38.00 & 67.1 & 82.3 & 85.7 & 89.1 & 94.0 & 35.00 & 64.4 & 79.5 & 83.0 & 86.5 & 94.6 \\
\hline & & 100 ppm & 36.31 & 63.3 & 78.5 & 83.0 & 87.4 & 92.5 & 27.12 & 57.5 & 72.5 & 78.0 & 83.5 & 88.7 \\
\hline & & 150 ppm & 28.30 & 56.8 & 72.0 & 77.7 & 84.5 & 91.6 & 25.28 & 54.3 & 69.3 & 76.9 & 84.4 & 87.7 \\
\hline & & Mean & 33.21 & 62.4 & 77.6 & 82.1 & 87.0 & 92.7 & 29.13 & 58.7 & 73.8 & 79.3 & 84.8 & 90.3 \\
\hline & & G Mean & 33.43 & 55.1 & 70.3 & 78.3 & 86.5 & 91.3 & 30.10 & 58.4 & 72.8 & 78.4 & 84.7 & 90.2 \\
\hline \multirow{14}{*}{ combined } & & Control & 14.91 & 30.5 & 45.7 & 62.3 & 79.0 & 89.4 & 17.00 & 30.3 & 55.4 & 64.2 & 75.0 & 87.8 \\
\hline & GA & $100 \mathrm{ppm}$ & 27.00 & 46.3 & 61.5 & 72.7 & 84.0 & 90.1 & 33.38 & 61.7 & 74.7 & 80.6 & 88.5 & 92.3 \\
\hline & & 200 ppm & 30.82 & 48.2 & 63.4 & 75.4 & 87.4 & 91.1 & 30.62 & 59.9 & 72.9 & 78.0 & 85.1 & 90.6 \\
\hline & & $300 \mathrm{ppm}$ & 30.18 & 52.5 & 67.7 & 78.8 & 89.9 & 91.8 & 28.30 & 55.7 & 70.7 & 77.0 & 83.4 & 90.0 \\
\hline & & Mean & 29.33 & 49.0 & 64.2 & 75.6 & 87.1 & 91.0 & 30.81 & 59.1 & 72.8 & 78.6 & 85.7 & 91.0 \\
\hline & IBA & 50 ppm & 34.70 & 60.7 & 75.9 & 80.9 & 86.0 & 92.7 & 27.03 & 57.0 & 72.1 & 77.9 & 84.7 & 91.0 \\
\hline & & $100 \mathrm{ppm}$ & 39.38 & 66.2 & 81.4 & 85.1 & 88.7 & 93.4 & 32.67 & 63.1 & 74.1 & 81.6 & 86.8 & 91.9 \\
\hline & & $150 \mathrm{ppm}$ & 35.72 & 61.8 & 77.0 & 82.9 & 88.8 & 93.2 & 34.50 & 58.0 & 73.0 & 77.6 & 83.6 & 90.8 \\
\hline & & Mean & 36.60 & 62.9 & 78.1 & 83.0 & 87.9 & 93.1 & 31.39 & 59.4 & 73.1 & 79.0 & 85.0 & 91.2 \\
\hline & MC & $50 \mathrm{ppm}$ & 39.20 & 68.1 & 83.3 & 86.7 & 90.1 & 95.0 & 36.78 & 66.2 & 81.3 & 84.8 & 88.3 & 95.5 \\
\hline & & $100 \mathrm{ppm}$ & 37.28 & 64.3 & 79.5 & 84.0 & 88.5 & 93.5 & 30.12 & 59.3 & 74.3 & 79.8 & 85.3 & 90.5 \\
\hline & & $150 \mathrm{ppm}$ & 31.92 & 57.8 & 73.0 & 78.7 & 85.5 & 92.6 & 26.70 & 56.1 & 71.1 & 78.7 & 86.2 & 89.5 \\
\hline & & Mean & 36.13 & 63.4 & 78.6 & 83.1 & 88.0 & 93.7 & 31.20 & 60.5 & 75.6 & 81.1 & 86.6 & 91.8 \\
\hline & & G Mean & 34.12 & 56.2 & 71.4 & 79.4 & 87.6 & 92.4 & 31.13 & 59.8 & 74.2 & 79.8 & 86.1 & 91.4 \\
\hline
\end{tabular}

${ }^{*}$ Combined LSD 5\% Giza 93 Combined LSD 5\% Giza 94 respectively (S): 0.320 .38 , (R): 0.380 .41 , (C) 0.410 .46 , (SxR) 0.510 .53 . (SxC) 0.540 .60 , (RxC) 0.580 .63 , (SxRxC) 0.720 .79 
Effect of the growth regulators foliar application on fiber perimeter (fiber fineness):

The results in Table (4) and figure (3) indicated that growing seasons, foliar application of the growth regulators treatments and their concentrations did not affect significantly fiber perimeter of the two studied varieties Giza 93 and Giza 94 along the different boll ages during the two growing seasons 2017 and 2018.

Table 4. Effect of the growth regulators and its concentrations on cotton fiber perimeter (Fiber fineness) of Giza 93 and Giza 94 variety in 2017 and 2018 seasons.

\begin{tabular}{|c|c|c|c|c|c|c|c|c|c|c|c|c|}
\hline \multirow{5}{*}{ Seasons } & \multirow{5}{*}{$\begin{array}{l}\text { PGR } \\
(R) \\
\end{array}$} & \multicolumn{11}{|c|}{ Fiber perimeter (fineness) } \\
\hline & & \multirow[t]{4}{*}{ Cocentrations (c) } & \multicolumn{5}{|c|}{ G.93 } & \multicolumn{5}{|c|}{ G.94 } \\
\hline & & & \multirow[b]{2}{*}{5} & \multicolumn{4}{|c|}{ Boll ages } & \multirow[b]{2}{*}{5} & \multicolumn{4}{|c|}{ Boll ages } \\
\hline & & & & 15 & 25 & 35 & $45-48$ & & 15 & 25 & 35 & 45-48 \\
\hline & & & days & day & Day & Day & days & days & day & day & day & days \\
\hline \multirow[t]{14}{*}{2017} & & Control & 36.8 & 39.3 & 40.6 & 43.4 & 46.7 & 39.5 & 42.3 & 45.7 & 49.5 & 51.2 \\
\hline & \multirow[t]{4}{*}{ GA } & $100 \mathrm{ppm}$ & 36.9 & 39.7 & 41.2 & 43.8 & 46.8 & 39.2 & 41.9 & 45.5 & 49.3 & 51.2 \\
\hline & & $200 \mathrm{ppm}$ & 36.5 & 39.5 & 41.2 & 43.6 & 46.7 & 39.5 & 42.1 & 45.4 & 49.3 & 51.2 \\
\hline & & $300 \mathrm{ppm}$ & 36.8 & 39.4 & 40.9 & 43.4 & 46.8 & 39.7 & 42.4 & 45.7 & 49.4 & 51.2 \\
\hline & & Mean & 36.7 & 39.5 & 41.1 & 43.6 & 46.8 & 39.4 & 42.1 & 45.5 & 49.4 & 51.2 \\
\hline & \multirow[t]{4}{*}{ IBA } & $50 \mathrm{ppm}$ & 37.3 & 39.7 & 41.1 & 43.6 & 46.8 & 39.3 & 42.2 & 45.6 & 49.5 & 51.3 \\
\hline & & $100 \mathrm{ppm}$ & 36.6 & 39.5 & 41.3 & 43.6 & 46.7 & 39.5 & 42.3 & 45.7 & 49.6 & 51.2 \\
\hline & & $150 \mathrm{ppm}$ & 36.9 & 39.5 & 41.2 & 43.6 & 46.9 & 39.1 & 42.0 & 45.5 & 49.6 & 51.1 \\
\hline & & Mean & 36.9 & 39.6 & 41.2 & 43.6 & 46.8 & 39.3 & 42.2 & 45.6 & 49.6 & 51.2 \\
\hline & \multirow[t]{5}{*}{ MC } & $50 \mathrm{ppm}$ & 35.7 & 39.2 & 41.6 & 43.8 & 46.8 & 39.8 & 42.5 & 45.8 & 49.5 & 51.4 \\
\hline & & $100 \mathrm{ppm}$ & 36.0 & 39.4 & 41.7 & 43.8 & 46.7 & 39.3 & 42.0 & 45.3 & 49.4 & 51.4 \\
\hline & & $150 \mathrm{ppm}$ & 37.0 & 39.9 & 41.8 & 43.8 & 46.8 & 39.2 & 42.0 & 45.5 & 49.5 & 51.2 \\
\hline & & Mean & 36.2 & 39.5 & 41.7 & 43.8 & 46.8 & 39.4 & 42.2 & 45.5 & 49.4 & 51.4 \\
\hline & & G Mean & 36.5 & 39.5 & 41.4 & 43.7 & 46.8 & 39.4 & 42.2 & 45.5 & 49.4 & 51.3 \\
\hline \multirow[t]{14}{*}{2018} & & Control & 36.9 & 39.4 & 40.7 & 43.5 & 46.8 & 39.4 & 42.3 & 45.7 & 49.4 & 51.1 \\
\hline & \multirow[t]{4}{*}{ GA } & $100 \mathrm{ppm}$ & 37.0 & 39.8 & 41.3 & 43.8 & 46.9 & 39.1 & 41.8 & 45.4 & 49.2 & 51.1 \\
\hline & & $200 \mathrm{ppm}$ & 36.6 & 39.5 & 41.3 & 43.7 & 46.8 & 39.4 & 42.1 & 45.4 & 49.2 & 51.1 \\
\hline & & 300 ppm & 36.9 & 39.5 & 41.0 & 43.5 & 46.9 & 39.6 & 42.3 & 45.7 & 49.4 & 51.1 \\
\hline & & Mean & 36.8 & 39.6 & 41.2 & 43.7 & 46.9 & 39.4 & 42.1 & 45.5 & 49.3 & 51.1 \\
\hline & \multirow[t]{4}{*}{ IBA } & $50 \mathrm{ppm}$ & 37.4 & 39.8 & 41.2 & 43.7 & 46.9 & 39.3 & 42.1 & 45.5 & 49.4 & 51.2 \\
\hline & & $100 \mathrm{ppm}$ & 36.6 & 39.5 & 41.4 & 43.7 & 46.8 & 39.4 & 42.2 & 45.7 & 49.5 & 51.1 \\
\hline & & $150 \mathrm{ppm}$ & 37.0 & 39.6 & 41.3 & 43.7 & 47.0 & 39.0 & 41.9 & 45.4 & 49.5 & 51.1 \\
\hline & & Mean & 37.0 & 39.6 & 41.3 & 43.7 & 46.9 & 39.2 & 42.1 & 45.5 & 49.5 & 51.1 \\
\hline & \multirow[t]{5}{*}{ MC } & $50 \mathrm{ppm}$ & 35.7 & 39.3 & 41.7 & 43.9 & 46.9 & 39.7 & 42.4 & 45.7 & 49.4 & 51.3 \\
\hline & & 100 ppm & 36.1 & 39.5 & 41.7 & 43.9 & 46.7 & 39.2 & 41.9 & 45.2 & 49.3 & 51.4 \\
\hline & & $150 \mathrm{ppm}$ & 37.1 & 40.0 & 41.9 & 43.9 & 46.9 & 39.1 & 41.9 & 45.4 & 49.4 & 51.1 \\
\hline & & Mean & 36.3 & 39.6 & 41.8 & 43.9 & 46.8 & 39.3 & 42.1 & 45.4 & 49.4 & 51.3 \\
\hline & & G Mean & 36.6 & 39.6 & 41.5 & 43.8 & 46.9 & 39.4 & 42.1 & 45.5 & 49.3 & 51.2 \\
\hline \multirow[t]{13}{*}{ Combined } & & control & 36.9 & 39.3 & 40.7 & 43.4 & 46.8 & 39.5 & 42.3 & 45.7 & 49.5 & 51.2 \\
\hline & GA & $100 \mathrm{ppm}$ & 36.9 & 39.7 & 41.3 & 43.8 & 46.9 & 39.1 & 41.9 & 45.4 & 49.3 & 51.2 \\
\hline & & 200 ppm & 36.5 & 39.5 & 41.3 & 43.7 & 46.8 & 39.4 & 42.1 & 45.4 & 49.3 & 51.2 \\
\hline & & $300 \mathrm{ppm}$ & 36.9 & 39.5 & 40.9 & 43.4 & 46.8 & 39.7 & 42.3 & 45.7 & 49.4 & 51.2 \\
\hline & & Mean & 36.8 & 39.6 & 41.2 & 43.6 & 46.8 & 39.4 & 42.1 & 45.5 & 49.3 & 51.2 \\
\hline & IBA & $50 \mathrm{ppm}$ & 37.3 & 39.8 & 41.2 & 43.7 & 46.8 & 39.3 & 42.1 & 45.6 & 49.4 & 51.2 \\
\hline & & $100 \mathrm{ppm}$ & 36.6 & 39.5 & 41.3 & 43.7 & 46.8 & 39.5 & 42.3 & 45.7 & 49.6 & 51.2 \\
\hline & & $150 \mathrm{ppm}$ & 37.0 & 39.5 & 41.2 & 43.7 & 46.9 & 39.1 & 41.9 & 45.5 & 49.5 & 51.1 \\
\hline & & Mean & 37.0 & 39.6 & 41.2 & 43.7 & 46.9 & 39.3 & 42.1 & 45.6 & 49.5 & 51.2 \\
\hline & MC & $50 \mathrm{ppm}$ & 35.7 & 39.2 & 41.6 & 43.9 & 46.9 & 39.8 & 42.4 & 45.8 & 49.5 & 51.3 \\
\hline & & $100 \mathrm{ppm}$ & 36.0 & 39.4 & 41.7 & 43.9 & 46.7 & 39.2 & 42.0 & 45.2 & 49.3 & 51.4 \\
\hline & & 150 ppm & 37.1 & 40.0 & 41.8 & 43.9 & 46.8 & 39.1 & 41.9 & 45.4 & 49.4 & 51.2 \\
\hline & & Mean & 36.3 & 39.5 & 41.7 & 43.9 & 46.8 & 39.4 & 42.1 & 45.5 & 49.4 & 51.3 \\
\hline Mean & & G Mean & 36.5 & 39.6 & 41.4 & 43.8 & 46.8 & 39.4 & 42.1 & 45.5 & 49.4 & 51.2 \\
\hline
\end{tabular}

*Combined LSD 5\% Giza 93 Combined LSD 5\% Giza 94. respectively (S): N.S N.S, (R): N.S N.S, (C): N.S N.S, (SxR): N.S N.S, (SxC): N.S N.S, $(R \times C)$ : N.S N.S, $(S \times R x C)$ : N.S N.S

\section{DISCUSSION}

Cotton fiber develops in orderly, precise pattern. Starting the day of flowering, cells of the surface of the ovule (unfertilized seed) start to elongate. Each lint fiber elongates for a period of 25-30 days to reach its final length depending on the variety and upon growth conditions. Elongation is slow at first; more rapid for a few days, then near the end of the elongation period, and it slows down again. The second stage of fiber growth is the thickening of fiber wall that begins after elongation has ceased. During this process, sugar produced from water and carbon dioxide through the photosynthesis processes is transported into the fiber, chemically converted into cellulose and deposited in successive layers on the inner wall surface. This thickening constitutes the fiber's secondary wall. This stage continues 20 to 30 days after elongation stage (Basra and Malik, 1984); however, an overlapping could be noticed between the two stages. 
From the obtained results, it could be concluded that foliar application of GA3 and IBA significantly increased fiber length along the different boll ages and accelerated fiber elongation rate, especially in the early boll ages of 5, 10, 15, and 20 days. Furthermore, fiber elongation increased to the 40th day of boll age but at a slower rate than in the early ages and continued during the cellulose deposition phase, indicating an overlapping between the elongation phase and the cellulose deposition phase. (Hake et al., 1991; Gould and Seagull, 2002; Ross et al., 2003; and Bhatt, 2007) came to similar conclusions. Salisbury and Ross (1992) reported that auxins stimulate cell elongation and cause wall loosening. GA3 and auxin act synergistically or additively in stimulating cell elongation. MC reduces or inhibits enzymes acting in the production of gibberellic acid concentrations in plants and consequently, inhibits growth and cell elongation (Halmann, 1990; Rademacher, 2000; and Stewart et al.,2001).

Cellulose deposition is a trait affected so much by environmental conditions and agronomic practices (the minimum temperature degrees in July, August, and September were higher in 2017 than in 2018 (table 1) which may enhance cellulose deposition in 2017 season). (El-Marakby et al.,2011) reported that growing season affected significantly cotton fiber cellulose deposition. Foliar application of growth regulators exerted an overlap between the elongation phase and cellulose deposition phase. This overlap started in the two varieties from the 20th day of boll age (during the elongation phase) to the 40th boll age. Chemical PGRs that promote, inhibit, or otherwise modify plant physiological or morphological processes have the ability to influence different stages of cotton fibre development.(Aleman et al.,2008; Singh et al.,2009; and Xiao et al.,2010). The auxin is necessary for secondary wall thickening (Kosmidou-Dimitropoulou, 1986), while, GA3 and auxin had no effect on cellulose synthesis (Francey et al.,1989; Jaquet et al., 1982; and Pillonel and Meier, 1985).

The only factor that affect fiber perimeter (fineness) in this study is the boll age where the thickening of the secondary is taking place, and force the primary wall to stretch increasing fiber perimeter. Cotton varieties by genetics differ in their intrinsic fineness (perimeter). Giza 93 which is an extra long extra fine cotton variety averaged 36.52, 39.55, 41.44, 43.75 and 46.81 microns for fiber Perimeter measured from the green bolls in 5, 15, 25, 35 boll ages up to $45-48$ boll age (the final boll age just before opening) respectively. Whereas, Giza 94 long staple Egyptian cotton variety averaged $39.39,42.11,45.59,49.39$ and 51.24 micron for fiber perimeter of the aforementioned boll ages. Fiber perimeter (fineness) is a varietal trait controlled mainly by genetics but affected by boll age. Fiber perimeter was affected by cotton variety and cellulose deposition (Gialvalis \& Seagull, 2001; Younis, 2010; and Sief et al., 2016).
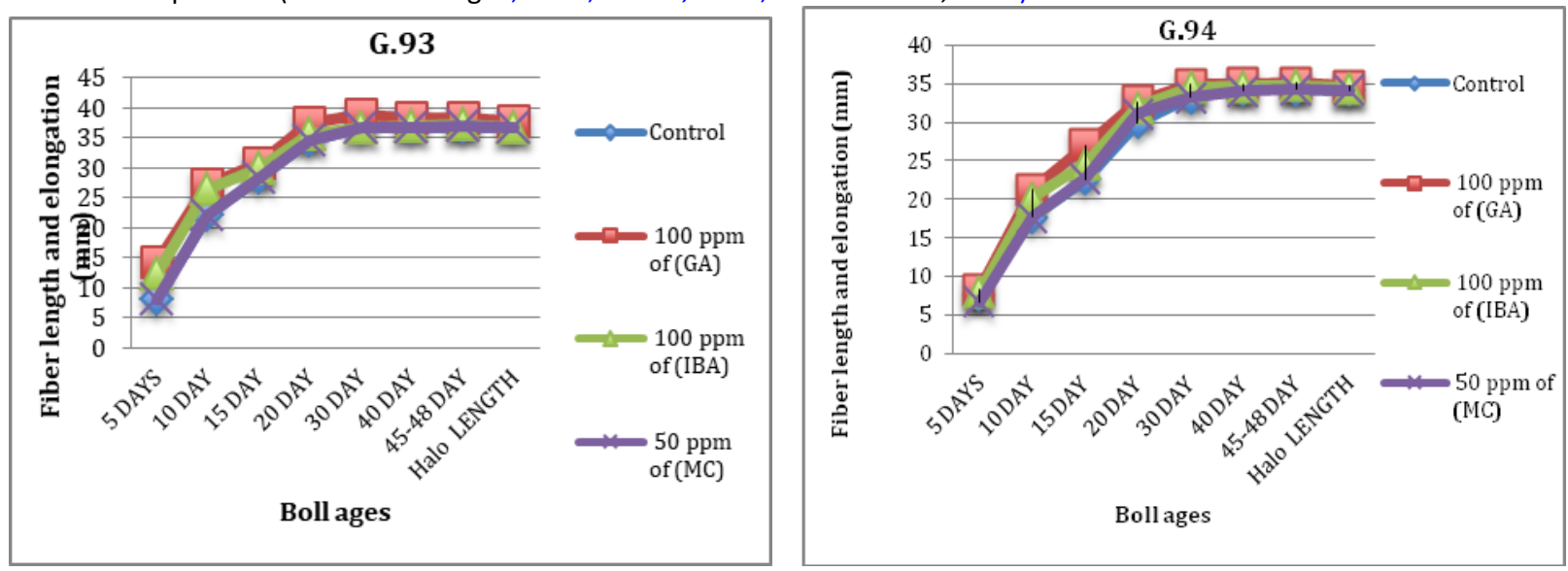

Fig. 1. Effect of the growth regulators and their concentrations on fiber length and elongation rate of G.93 and G.94 varieties in 2017 and 2018 seasons.
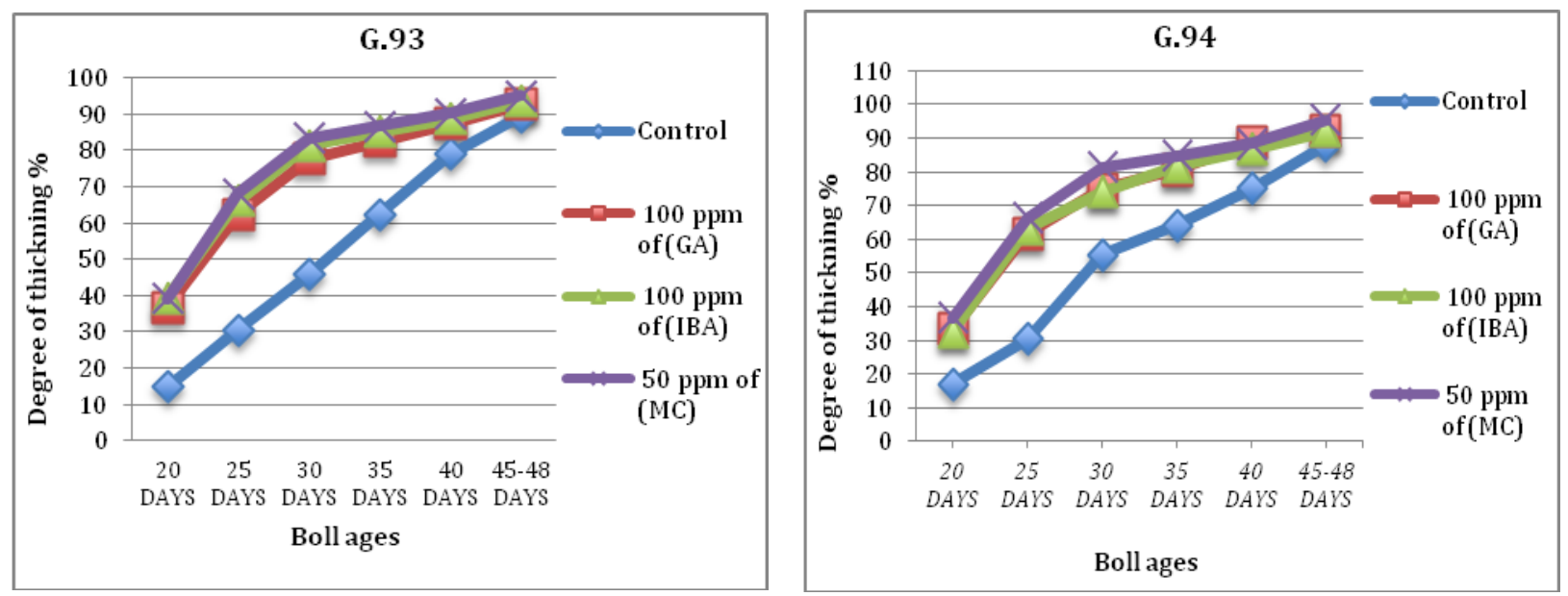

Fig. 2. Effect of the growth regulators and its concentrations on degree of thickening (fiber maturity) and its rate of G.93 and G.94 varieties in 2017 and 2018 seasons. 

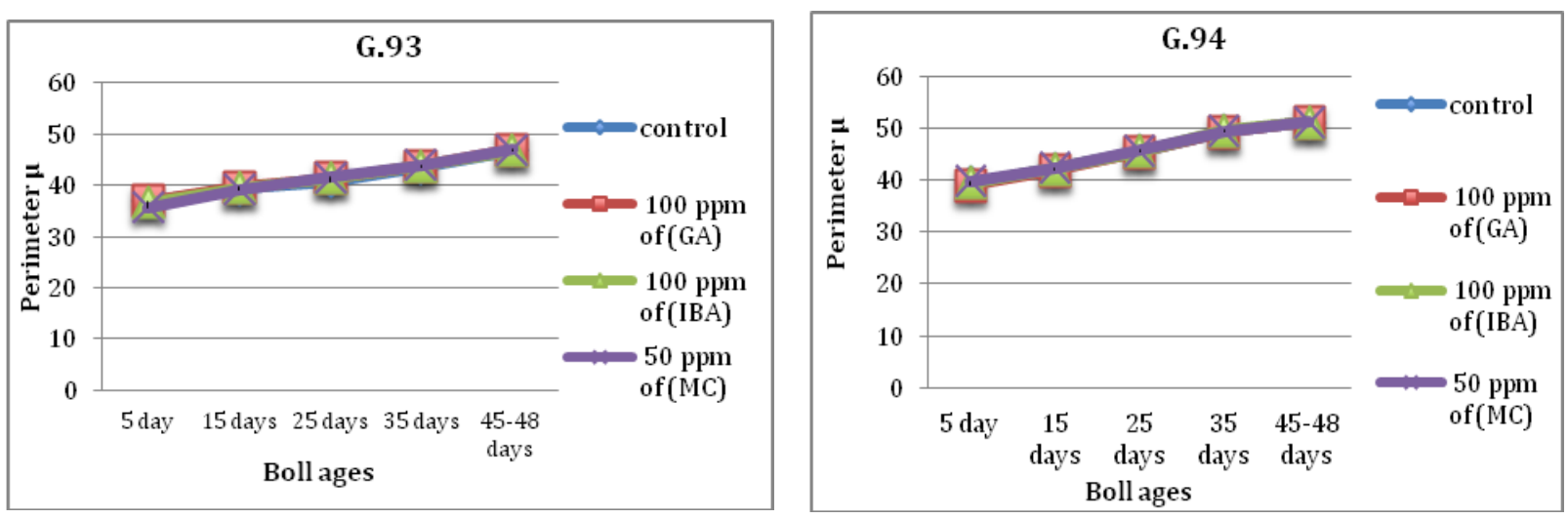

Fig. 3. Effect of the growth regulators and its concentrations on cotton fiber perimeter (Fiber fineness) of Giza 93 and Giza 94 variety in 2017 and 2018 seasons.

\section{CONCLUSION}

Foliar application of GA3 and IBA significantly increased fiber length along the different boll ages and accelerated fiber elongation rate. Foliar application treatment of 100 ppm of GA3 surpassed all the other treatments of the growth regulators in increasing fiber length of the different boll ages and in accelerating the elongation rate of G.93 and G.94. Foliar application of growth regulators exerted an overlap between the elongation phase and cellulose deposition phase. This overlap started in the two varieties from the 20th day of boll age (during the elongation phase) to the 40th boll age ( duing cellulose deosition). the $50 \mathrm{ppm}$ treatment of Pix, recorded higher values of this trait along the different boll ages compared to the other treatments of the three growth regulators. The only factor that affect fiber perimeter (fineness) in this study is the boll age where the thickening of the secondary is taking place, and force the primary wall to stretch increasing fiber perimeter

\section{REFERENCES}

Aleman, L., Kitamura, J., Abdel-Mageed, H., Lee, J., Sun, Y., Nakajima, M., ... \& Allen, R. D. (2008). Functional analysis of cotton orthologs of GA signal transduction factors GID1 and SLR1. Plant Molecular Biology, 68(1-2), 1.

ASTM D5867 (2005). "Standard Test Method for Measurement of Physical Properties of Cotton Fibers by High Volume Instruments." Annual Book of ASTM Standards. Vol. 7. 02.

Basra, A. S., \& Malik, C. P. (1984). Development o the cotton fiber International Review of Cytology, 87: 65 - 113.

Bhatt, K. R. (2007). Studies on Metabolic Changes Associated with Cotton Ovule Development in Vivo and in Vitro (Doctoral dissertation, Saurashtra University).

Clement, J. D. (2010). Effects of exogenously applied indole-3-acetic acid (IAA) to cotton. Texas A\&M University.

El-Marakby, A.M; Seif, M.G; Amal Z.A. Mohamed and Shimaa A. Younis (2011). Fiber fineness and maturity and their relation to other technological properties in15 Egyptian cotton genotypes. Egyptatin Journal of Plant Breeding 15 (3): $13-32$.

Francey, Y., Jaquet, J. P., Cairoll, S., Buchala, A. J., \& Meier, H. (1989). The biosynthesis of $\beta$-glucans in cotton (Gossypium hirsutum L.) fibres of ovules cultured in vitro. Journal of plant physiology, 134(4), 485-491.

Gialvalis, S., \& Seagull, R. W. (2001). Plant hormones alter fiber initiation in unfertilized, cultured ovules of Gossypium hirsutum. Journal of Cotton Science, 5(4), 252-258.

Gokani, S. J., \& Thaker, V. S. (2002). Role of gibberellic acid in cotton fibre development. The Journal of Agricultural Science, 138(3), 255-260.

Gokani, S. J., \& Thaker, V. S. (2002). Physiological and biochemical changes associated with cotton fiber development: IX. Role of IAA and PAA. Field Crops Research, 77(2-3), 127-136.

Gokani, S. J., \& Thaker, V. S. (2002). Role of gibberellic acid in cotton fibre development. The Journal of Agricultural Science, 138(3), 255-260.

Gould, P., \& Seagull, R. W. (2002). Increasing reversal frequency in Gossypium hirsutum L.'MD51'through exogenous application of plant hormones. Journal of Cotton Science 6, 52-59.

Goynes, W. R., Ingber, B. F., \& Triplett, B. A. (1995). Cotton Fiber Secondary Wall Development-Time Versus Thickness. Textile Research Journal, 65(7), 400-408.

Guilfoyle, T. J., \& Key, J. L. (1986). Auxin-regulated gene expression in higher plants. Critical Reviews in Plant Sciences, 4(3), 
247-276.

Hake, K., Kerby, T., McCarty, W., O'Neal, D., \& Supak, J. (1991). Physiology Today. National Cotton Council of America, 3(2).

Halmann, M. (1990). Synthetic plant growth regulators. Advances in Agronomy, 43, 47-105.

Jaquet, J. P., Buchala, A. J., \& Meier, H. (1982). Changes in the non-structural carbohydrate content of cotton (Gossypium spp.) fibres at different stages of development. Planta, 156(5), 481-486.

John, M. E., \& Keller, G. (1996). Metabolic pathway engineering in cotton: biosynthesis of polyhydroxybutyrate in fiber cells. Proceedings of the National Academy of Sciences, 93(23), 12768-12773.

Jost, P., Whitaker, J., Brown, S. M., \& Bednarz, C. (2006). Use of plant growth regulators as a management tool in cotton. University of Georgia Cooperative Extension Service Bulletin, 1305.

Key, J. L. (1989). Modulation of gene expression by auxin. Bioessays, 11(2-3), 52-58.

Kosmidou-Dimitropoulou, K., \& Board, H. C. (1986). Hormonal influences on fiber development. Cotton Physiology. The Cotton Foundation, Memphis, TN, 361-373.

Lee, J. J., Woodward, A. W., \& Chen, Z. J. (2007). Gene expression changes and early events in cotton fibre development. Annals of Botany, 100(7), 1391-1401.

Lord, E., \& Heap, S. A. (1981). The origin and assessment of cotton fibre maturity. Manchester, UK: International Institute for Cotton.

Marrè, E. (1977). Effects of fusicoccin and hormones on plant cell membrane activities: observations and hypothesis. In Regulation of Cell Membrane Activities in Plants; Proceedings of the International Workshop.

Naithani, S. C., Rao, N. R., \& Singh, Y. D. (1982). Physiological and biochemical changes associated with cotton fibre development: I. Growth kinetics and auxin content. Physiologia Plantarum, 54(2), 225-229.

Olszewski, N., Sun, T. P., \& Gubler, F. (2002). Gibberellin signaling: biosynthesis, catabolism, and response pathways. The Plant Cell, 14(suppl_1), S61-S80.

Oosterhuis, D. M., \& Robertson, W. C. (2000). The use of plant growth regulators and other additives in cotton production. Special Reports-University Of Arkansas Agricultural Experiment Station, 198, 22-32.

Oosterhuis, D. M., Wullschleger, S. D., \& Rutherford, S. (1991). Plant physiological responses to PIX. In Proc. 1991. Cotton Res. Meeting. University of Arkansas Agricultural Experiment Station, Special Report (Vol. 149, pp. 47-55).

Pillonel, C., \& Meier, H. (1985). Influence of external factors on callose and cellulose synthesis during incubation in vitro of intact cotton fibres with [14 C] sucrose. Planta, 165(1), 76-84.

Qin, Y. M., \& Zhu, Y. X. (2011). How cotton fibers elongate: a tale of linear cell-growth mode. Current Opinion in Plant Biology, 14(1), 106-111.

Rabadia, V. S., Thaker, V. S., \& Singh, Y. D. (1999). Relationship between water content and growth of seed and fibre of three cotton genotypes. Journal of Agronomy and Crop Science, 183(4), 255-261.

Rademacher, W. (2000). Growth retardants: effects on gibberellin biosynthesis and other metabolic pathways. Annual Review of Plant Biology, 51(1), 501-531.

Ross, J. J., O'Neill, D. P., \& Rathbone, D. A. (2003). Auxin-gibberellin interactions in pea: integrating the old with the new. Journal of plant growth regulation, 22(1), 99-108.

Seagull, R. W., Oliveri, V., Gialvalis, S., \& Gould, P. (2000, December). Changes in cotton fiber initiation and growth through the application of plant hormones to developing bolls. In Proc. Cotton Workshop on the Genetic Control of Fiber and Seed Quality, San Antonio, TX (pp. 4-6).

Sief, M. G., Rokaia, M. H. and Hanan, M. A. (2016). Effect of cotton fiber maturity on its fineness measurements. Egyptain Journal of Applied Scince 31 (10),240-255

Singh, B., Cheek, H. D., \& Haigler, C. H. (2009). A synthetic auxin (NAA) suppresses secondary wall cellulose synthesis and enhances elongation in cultured cotton fiber. Plant cell reports, 28(7), 1023-1032.

Smart, L. B., Vojdani, F., Maeshima, M., \& Wilkins, T. A. (1998). Genes involved in osmoregulation during turgor-driven cell expansion of developing cotton fibers are differentially regulated. Plant Physiology, 116(4), 1539-1549.

Snedecor, G. W., \& Cochran, W. G. (1986). Statistical analysis methods 7th ed.

Stewart, A. M., Edmisten, K. L., Wells, R., Jordan, D. L., \& York, A. C. (2001). Wick applicator for applying mepiquat chloride on cotton: I. Rate response of wick and spray delivery systems. Journal of Cotton Science, 5(1), 9-14.

Thaker, V. S., Saroop, S., Vaishnav, P. P., \& Singh, Y. D. (1986). Role of peroxidase and esterase activities during cotton fiber development. Journal of Plant Growth Regulation, 5(1), 17-27.

Xiao, Y. H., Li, D. M., Yin, M. H., Li, X. B., Zhang, M., Wang, Y. J., ... \& Pei, Y. (2010). Gibberellin 20-oxidase promotes initiation and elongation of cotton fibers by regulating gibberellin synthesis. Journal of Plant Physiology, 167(10), 829-837.

Younis, Shimaa A. Sh. (2010). Fiber Fineness and maturity and their relation to other technological properties in Egyptian cotton. Mast. Thesis, Fac. of Agric. Ain Shams Univ., Egypt. 
Zhao, D., \& Oosterhuis, D. M. (2000). Pix plus and mepiquat chloride effects on physiology, growth, and yield of field-grown cotton. Journal of Plant Growth Regulation, 19(4).

Copyright: (C) 2021 by the authors. Licensee EJAR, EKB, Egypt. EJAR offers immediate open access to its material on the grounds that making research accessible freely to the public facilitates a more global knowledge exchange. Users can read, download, copy, distribute, print or share a link to the complete text of the application under Creative Commons BY-NC-SA 4.0 International License. 


\section{تأثير الرش الورقي ببعض منظمات النمو علي نمو وتطور التيلة ( الأستطالة \& النضج) في صنفين من القطن المصري}

منير جاد سيف . حنان محمود عرفة ـ شيماء عبد ربه شحات

معهد بحوث القطن .- مركز البحوث الزراعية -. الجيزة ـ مصر

الملخص

أقيمت تجريتان حقليتان بمحطة التجارب الزراعية بسخا - كفر الشيخ التابعة لمركز البحوث الزراعية موسمي 2017 ، 200 ،

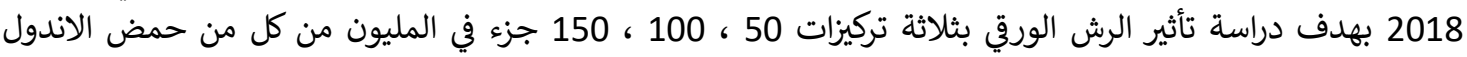

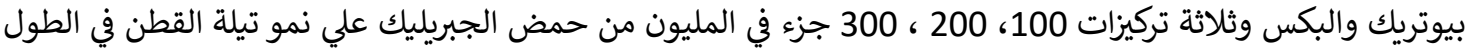

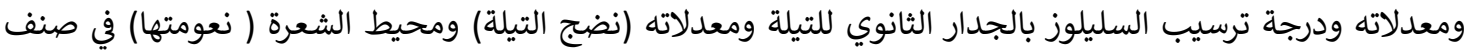

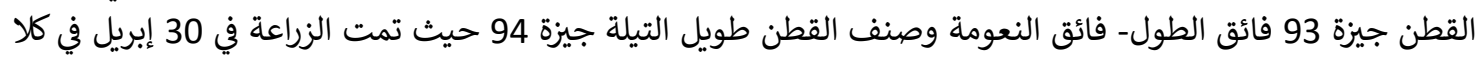

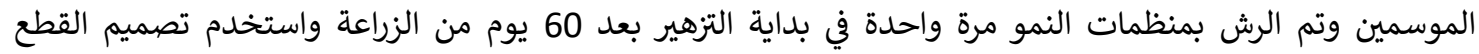

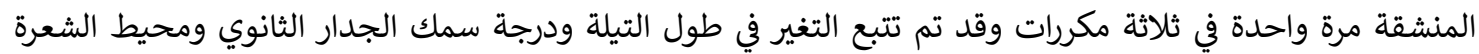

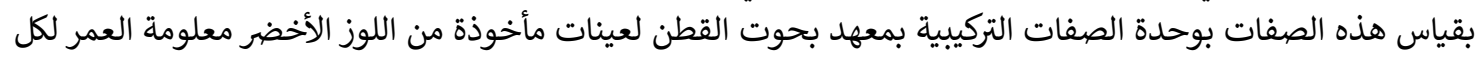

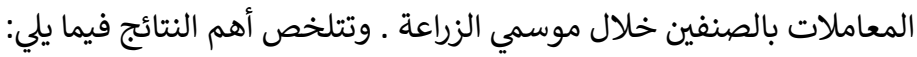

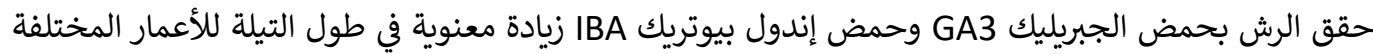

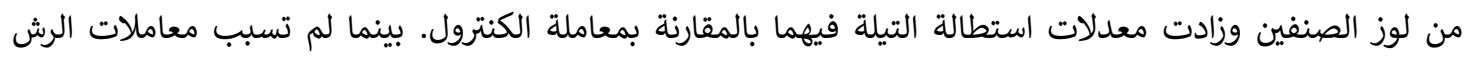
بالبكس بتركيزاته المختلفة اي تغير معنوي في استطالة التيلة في كلا الصنيف الصنين.

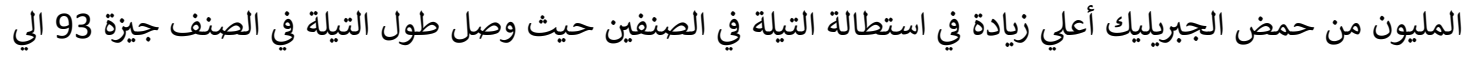

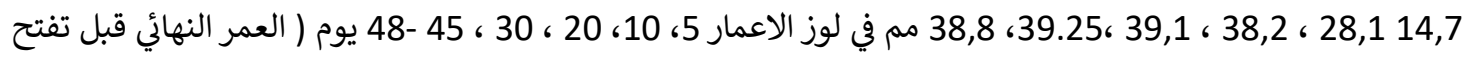

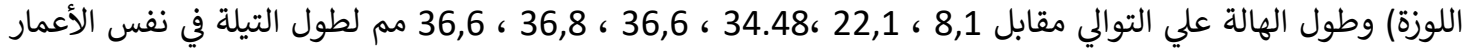

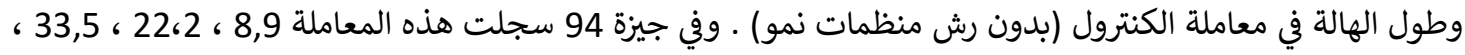

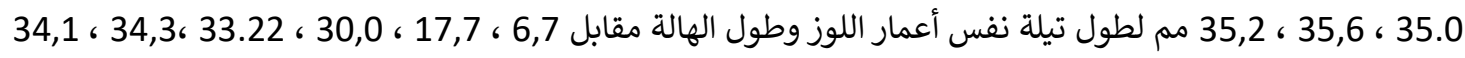

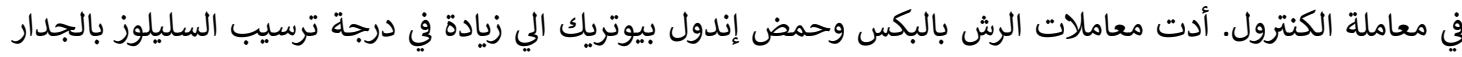

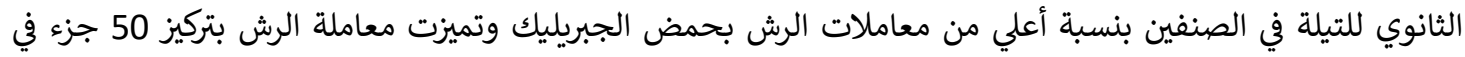

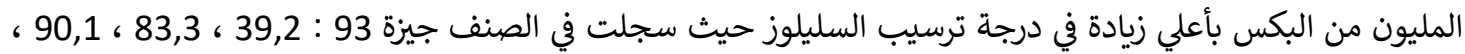

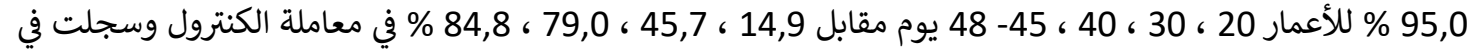

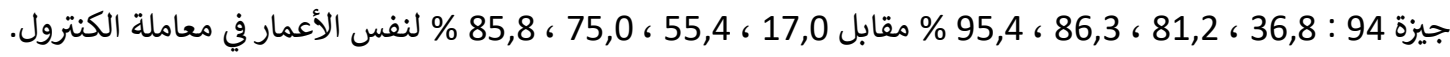

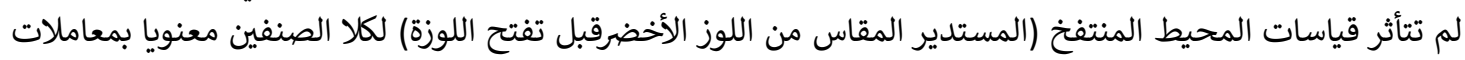

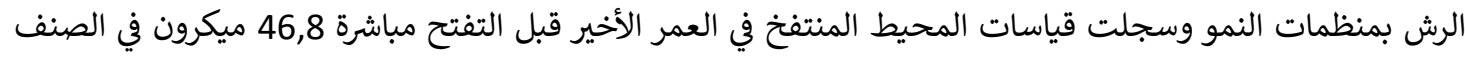

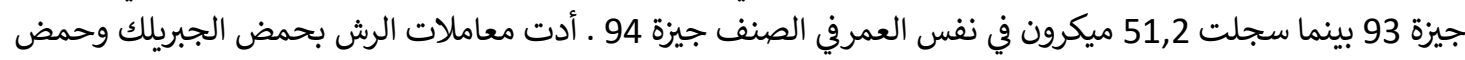

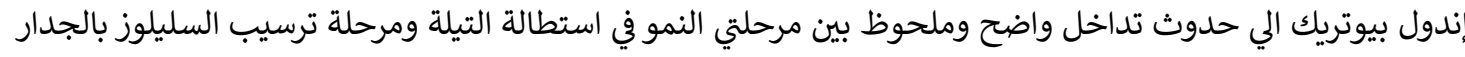

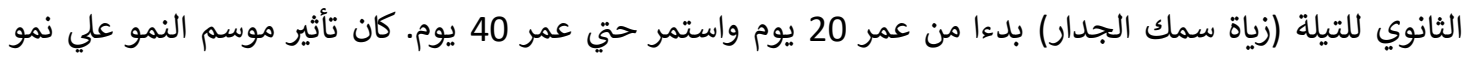

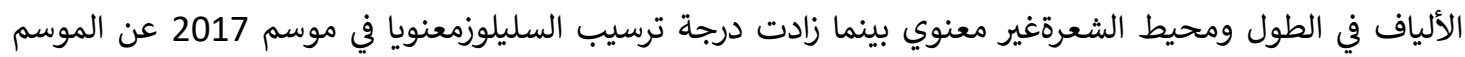

الكلمات المفتاحية: القطن ، الجودة ، تطور نمو الألياف ، منظمات النمو ، الرش الورقي 